\title{
P05.40. Traditional medicine and primary health care: leading examples from around the World
}

\author{
D Hollenberg ${ }^{1 *}, \mathrm{M} \mathrm{Torri}^{2}$ \\ From International Research Congress on Integrative Medicine and Health 2012 \\ Portland, Oregon, USA. 15-18 May 2012
}

\section{Purpose}

This paper will draw on recent ethnographic fieldwork to present and discuss leading examples of how traditional/indigenous medicine (TM) is used as primary healthcare (PHC) - or first point of contact - for diverse international communities. For the past 30 years, TM has been identified by policy-makers such as the WHO as essential for successful PHC, yet international development programs have yet to fully engage with TM projects "on the ground".

\section{Methods}

Data in this paper will draw on extensive ethnographic fieldwork within the identified countries under discussion.

\section{Results}

Two different and recent case studies will be presented to highlight the discussion: (1) Home Herbal Gardens (HHGs) in Bangalore, South India; and (2) TM practices in South East Asia (Indonesia). The data presented will focus on TM practices that enhance PHC along with social capital and community health. Using visual footage of TM practices, the presentation will conclude by demonstrating the vital importance of TM for PHC and community health worldwide.

\section{Conclusion}

Drawing on the presentation and the data under discussion, an arguement for validating and extending the role of TM in PHC will be made.

\footnotetext{
Author details

${ }^{1}$ Royal College of Physicians and Surgeons of Canada, Ottawa, Canada.

2University of New Brunswick, Department of Sociology, Fredericton, Canada.
}

${ }^{1}$ Royal College of Physicians and Surgeons of Canada, Ottawa, Canada Full list of author information is available at the end of the article
Published: 12 June 2012

doi:10.1186/1472-6882-12-S1-P400

Cite this article as: Hollenberg and Torri: P05.40. Traditional medicine and primary health care: leading examples from around the World. BMC Complementary and Alternative

Medicine 2012 12(Suppl 1):P400.
Submit your next manuscript to BioMed Central and take full advantage of:

- Convenient online submission

- Thorough peer review

- No space constraints or color figure charges

- Immediate publication on acceptance

- Inclusion in PubMed, CAS, Scopus and Google Scholar

- Research which is freely available for redistribution 